\title{
The Anticancer Activity of Marine Sponge Cinachyrella sp. (Family Tetillidae)
}

\author{
Awik Puji Dyah Nurhayati ${ }^{1}$, Rarastoeti Pratiwi ${ }^{2}$, Subagus Wahyuono ${ }^{3}$, Istriyati $^{2}$, \\ and Nichole J. De Voogt ${ }^{4}$
}

\begin{abstract}
Cinachyrella sp. marine sponge produce many kinds of secondary metabolites. The purpose of this study was to examine the cytotoxic and anti-proliferative activity of marine sponge Cinachyrella sp. The sponge was extracted with 96 $\%$ ethanol. Ethanol extract cytotoxicity assay were performed with MTT method (Microculture Tetrazolium) against to cell lines of HeLa, T47D, WiDr and Vero. The results show that of the ethanol extract were only toxic to cell lines of $\mathrm{HeLa}^{\mathrm{IC}} \mathrm{C}_{50}$ $897.809 \mu \mathrm{g} / \mathrm{mL}$ but did not toxic to cell lines of T47D, WiDr and normal cell lines of Vero. Fractionation of the ethanol extract was conducted by a Vacuum Column Chromatography (VCC) and have 4 fraction that were F1, F2, F3 and F4. Cytotoxicity and cell proliferation inhibitory were tested of fraction F1, F2, F3 and F4 against cell lines of T47D. The values $\mathrm{IC}_{50}$ of $\mathrm{F} 1$; F2; F3 and $\mathrm{F} 4$ against cell lines of T47D were $82.744 ; 163.679 ; 66.522$ and $333.026 \mu \mathrm{g} / \mathrm{mL}$ and fraction F3 concentration $31.5 \mu \mathrm{g} / \mathrm{mL}$ inhibits cell proliferation cell lines of T47D at 48 hours of incubation.
\end{abstract}

Keywords_Cinachyrella sp., MTT, Cell Lines HeLa, T47D, WiDr and Vero.

Abstrak-Spons laut Cinachyrella sp. menghasilkan banyak metabolit sekunder. Tujuan penelitian ini mengkaji sitotoksisik dan antiproliferasi spons laut Cinachyrella sp. Spons diekstraksi dengan etanol 96\%. Uji sitotoksisitas ekstrak ethanol dilakukan dengan Metode MTT (Microculture Tetrazolium) terhadap sel HeLa, T47D, WiDr dan Vero. Ekstrak ethanol menunjukkan sitotoksik terhadap sel HeLa dengan nilai $\mathrm{IC}_{50} 897,809 \mu \mathrm{g} / \mathrm{mL}$, tetapi tidak toksik terhadap sel T47D, WiDr dan Vero. Ekstrak ethanol difraksionasi dengan metode kromatografi kolom vakum (KKCV). Hasil fraksionasi diperoleh 4 fraksi F1, F2, F3 dan F4. Semua fraksi dilakukan uji sitotoksik dan anti-proliferasi terhadap sel T47D. Fraksi F1, F2, F3 dan F4 menunjukkan sitotoksik terhadap sel T47D dengan nilai $\mathrm{IC}_{50} 82,744 ; 163,679 ; 66,522$ dan 333,026 $\mu \mathrm{g} / \mathrm{mL}$ dan fraksi $\mathrm{F3}$ konsentrasi 31,5 $\mu \mathrm{g} / \mathrm{mL}$ menghambat proliferasi sel T47D pada inkubasi 24 jam.

Keywords-Cinachyrella sp., MTT, HeLa, T47D, WiDr, Vero.

\section{INTRODUCTION}

M arine sponges Cinachyrella sp. (phylum Porifera, class Demospongiae, order Spirophorida, family Tetillidae) is sessile marine invertebrates mostly spherical to elliptical. The sponge are characterized by a spherical and spiraling growth form. They are frequently referred to as "golf ball sponges" and "moon sponges' [1]. Cinachyrella $s p$. is dominant type of sponge in the intertidal beach Kukup [2].

They have been found to be a source of secondary metabolites with potential medical applications such hemagglutinating Aerythrocytes activity for papainized type mammalian ionotropic glutamate receptors [4], and antiproliferative activity against HeLa, PC3 and 3T3 cell lines [5]. Marine sponge Tetilla $\mathrm{sp}$. that was namely one family with Tetillidae have antibacterial activity against Escherichia coli and Staphylococcus aureus [6] and anticancer activity showed G0-G1 phase arrest cells lines WiDr [7].

Cancer is a devasting disease with tremendous negative implications at the personal, health care,

${ }^{1}$ Awik Puji D. N. is with Departement of Biology, Faculty of Mathematics and Science, Institut Teknologi Sepuluh Nopember, Surabaya, 6011, Indonesia, E-mail: awiknurhayati@gmailcom.

${ }^{2}$ Rarastoeti Pratiwi and Istriyati are with Departement of Biology, Universitas Gadjah Mada, Yogyakarta, 55281, Indonesia. Email:rarastp@yahoo.com.

${ }^{3}$ Subagus Wahyuono is with Departement of Farmacy, Universitas Gadjah Mada, Yogyakarta, 55281, Indonesia, Email:subagus@gmail.com.

${ }^{4}$ Nichole $\mathrm{J}$ de Voogt is Taxonomist of Marine Zoology Museum Darwinweg, Leiden, E-mail: nicole.devoogd@naturalis.nl economical and social level [8]. It is one of the leading causes of death in the World, aflicting an estimated 7.9 million people in 2007 World Health Organization (WHO), and this number continues to increase almost 80 million per year [9]. In Indonesia cancer patients also tended to increased [10].

Cancer develops due to failures in the mechanisms that normally control cell growth and proliferation. Therefore, losses in the regulation of these cells are, in most cases, caused by genetic damage [11]. Changes in the cell genome due to errors in DNA replication, DNA instability, but it is also caused by exposure to chemical carcinogens such as ionizing radiation and UV [12].

Conventional cancer treatment can be done in several ways: surgery, radiotherapy, chemotherapy, or in some cases, it is necessary to combine more than one method for treating the cancer. Several distinct biological strategies might prove effective in eliminating established tumors or preventing the maintenance of its progression [13].

In America and Europe estimated $65 \%$ of cancer drugs derived from natural materials commercially [14]. Derivative compounds of bioactive natural products have specific targets and has no side effects [15]. Marine sponges (Porifera) are the oldest metazoan group having an outstanding importance as a living fossil. Biomass of sponges is the largest and most diverse in marine habitats [16].

Sponge and symbiont microorganisms produce a number of secondary metabolites [17]. Sponges have been considered as a gold mine for the chemists. More than 12,000 compounds have been isolated from marine sources with hundreds of new compounds still being discovered every year [18]. Thirty percent of the natural ingredients that have been isolated from the 
sponge derived [19]. Many of these compounds function as chemical weapons and have evolved into highly potent inhibitors of physiological processes in the prey, predators [20], or competitors of the marine organisms that use them $[21,22]$.

This work was taken to investigate the cytotoxic and antiproliferative properties from marine sponge Cinachyrella sp. against to human tumor cell lines of HeLa, T47D, WiDr and normal cell line of Vero. This investigated to some other types of cancer cells, because cancer cells have characteristic and sensitivity of different molecular.

\section{METHOD}

\section{A. Sponge Collection}

Samples of Cinachyrella sp. were collected along tidal zones the south coast of Kukup, Gunung Kidul, Yogyakarta in 2011. The specimen was identified as Cinachyrella sp. by Dr. Nicole J. de Voogd. The voucher number for this collection is RMNH POR.8636 and a voucher sample is maintained at the Marine Zoology Museum Darwinweg, Leiden.

\section{B. Extraction and Purification}

The sponge $(15 \mathrm{~kg})$ extracted with ethanol $96 \%$ to give $448.31 \mathrm{~g}$ extract ethanol [23]. Further the extract ethanol was partitioned by ethyl acetate. Fractionation ethyl acetate extracts were separated by vacuum liquid column chromatography with silica gel stationary phase and mobile phase combined organic solvent N-Hexane: Ethyl acetate $(10: 0 ; 9 ; 1 ; 8: 2 ; 7: 3 ; 6: 4 ; 5: 5 ; 4: 6 ; 3: 7 ; 2: 8 ; 1: 9$; 0:10); Chloroform:Methanol=1:1. Fractions were evaporated and identified by thin layer chromatography/TLC with n-hexane $=7: 3 \mathrm{v} / \mathrm{v}$ as eluent [24]. Fractions with similarity TLC profiles are merged. The combined fractions (F) used to anticancer activity. Active isolate of fraction was isolation by preparative TLC (TLCP).

\section{Cell line and Culture}

The human servix cancer cell line HeLa (ATCC ${ }^{\circledR} \mathrm{CCL}$ $2^{\mathrm{TM}}$ ), breast cancer cell line T47D (ATCC ${ }^{\circledR} \mathrm{HTB}-133^{\mathrm{TM}}$ and colon cancer cell line WiDr (ATCC ${ }^{\circledR} \mathrm{CCL}-218^{\mathrm{TM}}$ ) were cultured in RPMI 1640 medium (Rosewell park memorian institute). The normal cell line Vero (ATCC ${ }^{\circledR}$ CCL-81 ${ }^{\mathrm{TM}}$ ) was cultured in M199 medium. The medium supplemented with $2 \mathrm{~mL}$ of penicillinstreptomycin $1 \%$ and $0.5 \% 1 \mathrm{~mL}$ fungizon. The cell cultures were grown in a humidified $5 \% \mathrm{CO}_{2}$ at $37 \mathrm{C}$.

\section{Cytotoxicity and Cell Viability Analysis}

The colorimetric MTT assay was used to determine cytotoxicity of extract ethanol and fraction marine sponge Cinachyrella sp. on HeLa, T47D, WiDr and Vero cells [25]. Briefly, 10,000 cells/well were seeded in 96-well plates. Cells were exposed to different concentrations of extract $(15.625 ; 31.25 ; 62.5 ; 125 ; 250$; $500 ; 1000 \mu \mathrm{g} / \mathrm{mL}$ in $1 \mathrm{ml}$ of sterile $10 \%$ DMSO). Control group was added $100 \mathrm{~mL}$ Doxorubicin (1.562; $3.125 ; 6: 25 ; 12.5 ; 25 ; 50 ; 100 \mu \mathrm{g} / \mathrm{mL})$ for $24 \mathrm{~h}$. Cells were then incubated with MTT solution $(4 \mathrm{mg} / \mathrm{mL}$ in $\mathrm{PBS}$ ) for $3 \mathrm{~h}$ at $37 \mathrm{C}$ in dark. Results of the MTT assays were obtained using a microplate reader (ELISA) at 595 $\mathrm{nm}$. The $\mathrm{IC}_{50}$ value was defined as the concentration that caused a $50 \%$ inhibition of cell growth compare to control RPMI. Each experiment was in triplicate format.

Determination of the concentration of sponge for toxicity tests follow the guidelines the American National Cancer Institute [26]. The extract have significant antiproliferative effects when LC $_{50}$ values $\leq$ $20 \mu \mathrm{g} / \mathrm{mL}$. Cytotoxicity was determined using $\quad[\{1-$ (OD treated/OD control) $\} \times 100]$ [27].

\section{E. Cell Growth Inhibition Assay}

Cell proliferation assay T47D cells $\left(1 \times 10^{3}\right.$ cells/well $)$ were plated in 96-well tissue culture microplates in 100 $\mu \mathrm{L}$ of medium and treated 24,48 and $72 \mathrm{~h}$ later with $\mathrm{F}$ in triplicate at 3 different concentrations $31.25 ; 62.5$ and $125 \mu \mathrm{g} / \mathrm{mL}$. The absorbance was monitored at 595 $\mathrm{nm}$ and results were expressed as the inhibition of cell proliferation calculated using $\left[\left(\begin{array}{lll}1 & -\end{array}\right.\right.$ (OD595 treated/OD595 control) $\times 100]$. Cell doubling time (doubling time) is obtained from equation curve relationship between incubation time and cell number (\%).

\section{F. Statistical Analysis}

Data cytotoxicity assay and cell proliferation kinetics were analyzed statistically by analysis of variance (ANOVA) one way using SPSS 13. Value Inhibitor Concentration 50 (IC 50 ) was determined using probit analysis with the help of the statistical program SPSS 13 [28].

\section{RESULT AND DISCUSSION}

Cinachyrella sp. is globular sponges of max. 4-5 $\mathrm{cm}$, with upper surface heavily covered by dark sediment and algae. Colour is orange, buds are yellow [29] Fig. 1. Sponges are usually found on firm surfaces such as rocks, but some sponges can attach themselves to soft sediment by means of a root-like base. The morphology and structure of the marine sponge Cinachyrella sp. is similar with Cinachyrella arabica [30].

\section{A. The Extract Ethanol and Fraction of Cinachyrella sp-induced Cytotoxicity in HeLa, T47D, WiDr and Vero Cells}

To investigate extract ethanol and fraction inhibited on HeLa, T47D, WiDr and Vero cells were treated with different doses $(15.625-1000 \mu \mathrm{g} / \mathrm{mL})$. These results were expressed as percent viability and as total number of viable cell as shown in Fig. 2. In the statistical analysis of Duncan's one way to T47D, WiDr and Vero cells showed no significant $(\mathrm{P}<0.05)$ and inhibit weak in HeLa cells. The ethanol extracts Cinachyrella sp. is sensitive for Hela cells lines.

Test results of fraction against cell lines T47D, WiDr and Vero showed in Fig. 3 and Table 2. Cytotoxicity of the fraction (F1, F2, F3 and F4) Cinachyrella sp. on cell lines T47D at a 24-h incubation time. Cell viability was measured using the MTT assay and expressed as the percentage of treated samples to untreated control samples. The percent viability on cell lines HeLa, T47D, WiDr and normal cell lines Vero increased. Statistical analysis of the active fraction Duncan two way showed a significant $(\mathrm{P}<0.05)$.

The ethanol is an organic solvent that general nature of all organic material. Identification by TLC of the extract 
ethanol and fractions of F1, F2, F3 and F4 by Dragendorf reagents and compounds of Cerium sulfate showed alkaloids and terpenoids.

Test anticancer activity is influenced by the type of extract and cell lines. The ethanol is more toxic against cell lines HeLa however ethyl acetate is more toxic to T47D cells [31]. The extract ethanol was polar and nonpolar compounds [32] while the extract ethyl acetate more interested semipolar and nonpolar compounds such as polyphenols group, alkaloids, flavonoids and glycosides. The results of this study indicate that the toxic compounds from the marine sponge Cinachyrella sp. is semipolar and nonpolar. In some other studies, nonpolar compounds more toxic than polar compounds. The ethyl acetate extract of the marine sponge Petrossian sp., Jaspis sp. and Pericharax heteroraphis have a higher cytotoxicity of the hexane extract and butanol [33]. The value IC 50 of extract ethyl acetate of red seaweed Gracilaria verrucosa against cell lines HeLa was 220.09 ppm, 62.5\% higher than the dichloromethane extract $37.5 \%$ [34]. The results of cytotoxicity assay ethanol extract marine sponge Cinachyrella sp. This is less toxic than the ethanol extract of the marine sponge Aaptos suberitoides Pasir Putih, Situbondo, East Java. The value IC ${ }_{50}$ ethanol extract of marine sponge A. suberitoides against cell lines HeLa, T47D and WiDr were 133.968; 153.109 and $144.540 \mu \mathrm{g} / \mathrm{mL}$ [35].

Alkaloids are microtubule interfere agents which can bind with beta tubulin, thus preventing the cell from making the mitotic spindle fibres necessary to move the chromosomes around as the cell divides [36], inhibiting topoisomerase [37], mitochondrial damage and inducing the release of cytochrome $\mathrm{C}$ and apoptosis inducting factor. Examples that the trifluoroacetat salt of Cinachyramine was isolated from the Okinawan sponge Cinachyrella sp. Cinachyramine is a novel alkaloid with an unprecedented cage system possessing a hydrazone and two aminals [38]. Enigmazole A, a noval phosphatecontaining macrolide, was isolated from Papua New Guinea collection of the marine sponge $C$. anigmatica. The enigmazole are the first phosphomacrolides from a marine source and exhibited significant cytotoxicity in the NCI 60-cell line antitumor screen, with a mean $\mathrm{GI}_{50}$ of $1.7 \mu \mathrm{M}$ [39].

Terpenoids display a wide range of biological activities against cancer, malaria, inflammation, and a variety of infectious diseases [40]. In marine waters is estimated there are hundreds of drugs derived from terpenoid compounds [41]. Triterpene B compound from marine sponge Globostellifera stellate and Geodia stellate were taken from ocean Fijian have anticancer activity against tumor cell lines A2780 and cell lines leukemia K562 [42]. Sesquiterpenes quinine isolated from sponges Hippospongia sp. have activity against human tumor cell lines H460, Hep G2, SF268, MCF7, HeLa and HL60 also caused arrest cycle cell lines HepG2 [43].

Different sensitivity of cell lines caused different molecular characteristics of cell lines. Jennei reported that cell lines TD7D expressed the estrogen receptor subtype $\beta$ [44]. Cell lines Vero which had been known as a normal cell from a normal cell derivate African Green Monkey is also potentially lead to tumor phenotypes [45]. The cell lines Vero often used as vaccine trials [46].
Inhibitory proliferation potency based on American National Cancer Institute of extract IC ${ }_{50}$ values $\leq 100$ $\mu \mathrm{g} / \mathrm{mL}$. Threshold set for natural ingredients that can be developed as anticancer $\leq 50 \mu \mathrm{g} / \mathrm{mL}$ [26]. Active isolate of fraction F3 of marine sponge Cinachyrella sp. at Kukup beach have potential as an anticancer agent.

\section{B. Antiproliferative effect of fraction Cinachyrella sp. on T47D Cell}

Logarithmically growing cell line T47D were seeded at a concentration $1 \times 10^{3}$ cells per $\mathrm{mL}$ and then incubated with increasing concentration of fraction Cinachyrella inhibited the growth of T47D cell. After 24 h, $48 \mathrm{~h}$ and $72 \mathrm{~h}$ of incubation Cinachyrella sp.inhibit the growth of T47D cells. The fraction F4 $31.5 \mu \mathrm{g} / \mathrm{mL}$ inhibited proliferative T47D cells (Table 3 and Fig. 6).

Differented response of cell lines to various types of sponges from various regions thought to be caused due to contained different active ingredients which each extract and isolate have components of different compounds [44]. Besides the secondary metabolites of the sponge is also influenced by water conditions, and the type of sponge symbiont organisms [47, 48, 49]. The ethanol extract is a mixture of various compounds, while the isolate was isolated compounds that contain more specific compounds. The ethyl acetate extract contains many alkaloids and terpenoids compounds that are more toxic than the ethanol extract.

Cinachyrella sp. also contained fatty acids,such as. phospholipid fatty acid composition of the sponge $C$. alloclada Senegal are two new fatty acids hitherto not found in nature 10,13-octadecadienoic acid and 16tricosenoic acid [50]. Class composition of phospholipids, fatty acids and sterols from the sponge $C$. alloclada and $C$. kükenthali of the Saudi Arabian Red Sea and in Senegal (East Atlantic) and New Caledonia (West Pacific) over 50 fatty acids were identified as methyl esters and $\mathrm{N}$-acyl pyrrolidides. Comparison with Cinachyrella species from other geographical areas showed marked differences for both the fatty acid composition of phospholipids and sterols [51]. Lectin protein as the Cinachyrella galectin (CchGs) in aqueous sponge extract that modulated the function of mammalian ionitropic glutamate. There are significant correlations between high anticancer activity and the high phenolic contents [52].

\section{CONCLUSION}

Marine sponges Cinachyrella sp. are potential sources of many unique metabolites, including cytotoxic and anticancer compounds to human tumor cell lines of T47D. The values $\mathrm{IC}_{50}$ of active isolate of fraction F3 $66.522 \mu \mathrm{g} / \mathrm{mL}$. Isolate active of fraction F3 concentration $31.5 \mu \mathrm{g} / \mathrm{mL}$ inhibits cell proliferation at 48 hours of incubation

\section{ACKNOWLEDGEMENTS}

The authors are grateful for the support provided by Sepuluh November Institute of Technology and DIKTI. This research is part of Doctoral study of first author in Universitas Gadjah Mada (UGM) Yogyakarta. The authors would like to gratefully appreciate these financial supports 


\section{REFERENCES}

[1] A Szitenberg et al., "Phylogeny of Tetillidae (Porifera, Demospongiae, Spirophorida) Based on Three Molecular Markers," Molecular Phylogenetics and Evolution, vol. 67, no. 2, pp. 509-519, February 2013.

[2] A P D Nurhayati, R Pratiwi, B Wahyuono, and Istriyati, Kajian Antikanker dengan Pendekatan Seluler dan Upaya Pelestarian Spons Laut Cinachyrella.sp di Tanjungsari, Gunung Kidul, 2011, Research Grants Based EfSD Program IMHERE, Faculty of Biology, Universitas Gajah Mada.

[3] D S Medeiros et al., "Lactose Specific Lectin from the Sponge Cinachyrella Apion: Purification, Characterization, N-terminal Sequences Alignment and Agglutinating Activity on Leishmania Promastigotes," Comparative Biochemistry and Physiology Part B: Biochemistry and Molecular Biology, vol. 155, no. 3, pp. 211216, March 2010

[4] T Ueda et al., "Isolation of Novel Prototype Galectins from the Marine Ball Sponge Cinachyrella sp. guided by their Modulatory Activity on Mammalian Glutamate-Gated Ion Channels," Glycobiology, vol. 23, no. 4, pp. 412-25, April 2013.

[5] L Rabelo et al., "A Lactose-Binding Lectin from the Marine Sponge Cinachyrella Apion (Cal) Induces Cell Death in Human Cervical Adenocarcinoma Cells," Marine Drugs, vol. 10, no. 4, pp. 727-743, April 2012.

[6] D P Perkasa and A Budiyanto, "Isolation and Antibacterial Activity of Sponge Cinachyrella sp.," Center for the Application of Isotope and Radiation Technology, BATAN, Jakarta, Research Report 2010.

[7] Amy E Wright, Isolation of Marine Natural Product, Richard J P Cannell, Ed. New York, USA: Humana Press, 1998.

[8] M F Ullah and M Aatif, "The Footprints of Cancer Development : Cancer Biomarker," Cancer Treatment Reviews, vol. 35, no. 3, pp. 193-200, May 2009

[9] P Maxwell, "Global Cancer Statistic in the Year 2000," The Lancet Oncology, vol. 2, no. 9, pp. 533-543, September 2001.

[10] D Tjindarbumi and R Mangunkusumo, "Cancer in Indonesia, Present and Future," Journal of Clinical Oncology, vol. 32, no. Supplement 1, pp. 17-21, August 2002.

[11] Lewis J Kleinsmith, Principles of Cancer Biology. San Francisco, USA: Pearson Benjamin Cummings, 2006.

[12] M Hejmadi. (2010) bookboon.com. [Online]. http://bookboon.com/en/introduction-to-cancer-biology-ebook.

[13] V T Devita and E Chu, "A history of Cancer Chemotherapy," Cancer Res, vol. 68, no. 21, pp. 8643-8653, November 2008

[14] J S Bertram, "Review: The molecular biology of cancer," Molecular Aspects of Medicine, vol. 21, no. 6, pp. 167-223, December 2001.

[15] S Y Wei et al., "Induction of Apoptosis Accompaniying with G1 Phase Arrest and Microtubule Disassembly in Human Hepatoma Cells by Jaspolide B, a New Isomala-Baricane-Type Triterpene," Cancer Letters, vol. 262, no. 1, pp. 114-122, April 2007.

[16] A Iwamaru et al., "Eupalmarea Acetate, a Novel Anticancer Agents from Caribbean Gorgonian Octocorals, Induces Apoptosis in Malignant Glioma Cells via the c-jun NH2-terminal Kinase Pathway," Molecular Cancer Therapeutics, vol. 6, no. 1, pp. 184192, January 2007.

[17] T Hochmuth et al., "Linking Chemical and Microbial Diversity in Marine Sponges; Possible Role for Poribakteria as Producers of Methyl-Branched Fatty Acids," ChemBioChem, vol. 11, no. 18, pp. 2572-2578, December 2010

[18] P Sima and V Vetvicka, "Bioactive Substances with AntiNeoplastic Efficacy from Marine Invertebrates Porifera and Coelenterata," World Journal of Clinical Oncology, vol. 10, no. 11, pp. 355-361, November 2011

[19] Y Murti and T Agrawal, "Marine Derived PharmaceuticalsDevelopment of Natural Health Products from Marine Biodiversity," International Journal of Chem Tech Research, vol. 2, no. 4, pp. 2198-2217, Oct-Dec 2010.

[20] J C Brackman and D Doloze, "Chemical Defence in Sponges," Pure and Applied Chemistry, vol. 58, no. 3, pp. 357-364, 1986.

[21] P J Schupp et al., "Cancer Chemopreventive and Anticancer Evaluation of Extracs and Fractions from Marine Macro and Micro-organism Collected from Twilight zone Waters Around Guam,", Vol. 4, No. 12, pp. 1717-1728, 2009.," Natural Product Communications, vol. 4, no. 12, pp. 1717-1728, December 2009.

[22] W E Müller et al., "Sustainable Production of Bioactive Compounds by Sponges-Cell Culture and Gene Cluster Approach: A Review.," A Review Marine Biotechnology, vol. 6, no. 2, pp. 105-117, Mar-Apr 2004
[23] B Dhorajiya, M Malani, and D Dholakiya, "Extraction and Preservation Protocol of Anti-Cancer Agents from Marine World," Chemical Sciences Journal, vol. 3, pp. 321-324, may 2012.

[24] R Agustina, G Alam, R Syukur, C Lethe, and A Rahim, "Ekstraksi dan Fraksinasi Senyawa Bioaktif Antimitosis dari Spons Callispongia hispidoconulosa," Majalah Farmasi dan Farmakologi, vol. 17, no. 1, pp. 21-24, Maret 2013.

[25] E Aziz et al., "Molecular Analysis of Men1expression in MCF7, T47D and MDA-MB 468 Breastcancer cell lines treated with Adriamycin using RT-PCR and Immunocytochemistr," DARU Journal of Pharmaceutical Sciences, vol. 18, no. 1, pp. 17-22, 2010.

[26] National Cancer Institute (NCI). (2012) National Cancer Institute (NCI). [Online]. http://www.cancer.gov/Published content/Images/document/cancer 4- new.

[27] S Kaabinejadian, Sh Fouladdel, M Ramezani, and E Azizi, "p53 Expression in MCF7, T47D and MDA-MB 468 Breastcancer Cell Lines Treated with Adriamycin using RT-PCR and Immunocytochemistry," Journal of Biological Sciences, vol. 8, no. 2, pp. 380-385, 2008.

[28] W Mao et al., "A Rapid Fuorescent Screening Method for Cellular Sensitivity to Anti-Cancer Compound," Cytotechnology, vol. 64, no. 4, pp. 451-457, August 2012.

[29] B Hartman, Character of Spong Cinachyrella sp., 1975, Cited for Nucleotide Sequence GenBank Sponge, DDBJ Database.

[30] WoRMS - World Register of Marine Species and Rob van Soest. (2009, January) WoRMS - World Register of Marine Species. [Online].

http://www.marinespecies.org/aphia.php?p=taxdetails\&id=38011 7.

[31] R Ruzicka and D Gleason, "Sponge Community Structure and Anti-Predator Defenses on Temperate Reefs of the South Atlantic Bight," Journal of Experimental Marine Biology and Ecology, vol. 380, no. 1-2, pp. 36-46, November 2009.

[32] G Beedesseea et al., "Cytotoxic Activities of Hexane, Ethyl Acetate and Butanol Extracts Ofmarine Sponges from Mauritian Waters on Human Cancer Cell Lines," Environmental Toxicologi and Pharmacology, vol. 34, no. 2, pp. 397-408, September 2012.

[33] Badraen, Kasmiati, and E A Zainuddin, "Isolasi Bahan Aktif Rumput Laut sebagai Kandidat Obat Antikanker dan Antibakteri Patogen pada Manusia," Universitas Hasanuddin, Makassar, Lecturer Research Report 2010.

[34] A P D Nurhayati, R Pratiwi, R Sukardiman, and E Zulaika, "Skrining, Isolasi dan Evaluasi Antikanker dari Spons Laut. Sub Judul: Evaluasi In Vivo dan Sitotoksisitas Antikanker dari Spons Laut Aaptos suberitoides," STRAGNAS, Institut Teknologi Sepuluh Nopember , Surabaya, Lecturer Research Report 2010

[35] R Solanki, M Khanna, and R La, "Bioactive Compounds from Marine Actinomycetes," Indian Journal of Microbiology, vol. 48, no. 4, pp. 410-431, December 2008.

[36] M Facompré et al., "Lamellarin D: A Novel Potent Inhibitor of Topoisomerase I," Cancer Res, vol. 63, no. 21, pp. 7392-7399, November 2003.

[37] H Shimogawa, S Kuribayashi, T Teruya, K Suenaga, and H Kigoshi, "Cinachyramine, The Noval Alkalid Possessing a Hydrazone and Two Aminals from Cinachyrella sp.," Tetrahedron Letters, vol. 47, no. 9, pp. 1409-1411, February 2006.

[38] N Oku et al., "Isolation, Structural Elucidation, and Absolute Stereochemistry of Enigmazole A, a Cytotoxic Phosphomacrolide from the Papua New Guinea Marine Sponge Cinachyrella Anigmatica," Journal of American Chemical Society, vol. 132, no. 30, pp. 10278-10285, August 2010.

[39] D J Newman, G M Cragg, and K M Snader, "The Influence of Natural Products Upon Discovery," Natural Product Report, vol. 17, no. 3, pp. 215-234, June 2000.

[40] T Lindel et al., "Eleuterobin, a New Cytotoxian that Mimics Paxlitaxel (taxol) by Stabilizing Microtubules," Journal of The American Chemichal Society, vol. 119, no. 37, pp. 8744-8745, September 1997.

[41] G Wang, W Tang, and R R Bridigare, Terpenoids As Therapeutic Drugs and Pharmaceutical Agents, L Zhang and Arnold L Demain, Eds. New York, USA: Humana Press, 2005.

[42] J N Tabudravu and M Jaspars, "Stelliferin Riboside, a Triterpene Monosaccharide Isolated from the Fijian Sponge Geodia Globostellifera," Journal of Natural Product, vol. 64, no. 6, pp. 813-815, June 2001

[43] H Liu et al., "Sesquiterpene Quinines from a Marine Sponge Hippospongia sp. that Inhibit Maturation of Starfish Oocytes and 
Induce cell cycle Arrest with Hep G2 cells," Pharmaceutical Biology, vol. 44, no. 7, pp. 522-527, January 2006.

[44] M Fountoulakis, G Tsangaris, J E Oh, A Maris, and G Lubec, "Protein Profile of the HeLa Cell Line," Journal of Chromatography, vol. 1038, no. 1-2, pp. 247-265, June 2004.

[45] M Manohar, B Orrison, K Peden, and A M Lewis, "Assessing the Tumorigenic Phenotype of VERO Cells in Adult and Newborn Nude Mice," Biologicals, vol. 36, no. 1, pp. 65-72, January 2008.

[46] A Kamuhabwa, C Nshimo, and P de Witte, "Cytotoxicity of Some Medicinal Plants Extract Used in Tanzanian Tradicional Medicine," Journal of Ethnopharmacol, vol. 70, no. 2, pp. 143149, May 2000.

[47] A F Coutinho, B Chanas, T M e Souza, I C P P Frugrulhetti, and R A Epifanio, "Anti HSV-1 Alkaloids from a Feeding Deterrent Marine Sponges of The Genus Aaptos.," Heterocycles, vol. 57, no. 7 , pp. 1265-1272, January 2002.
[48] E Larghi, B Obrist, and T Kaufman, "A Formal Total Synthesi of The Marine Alkaloid Aaptamine," Tetrahedron, vol. 64, no. 22, pp. 5236-5245, May 2008.

[49] A M S Meyer and R G Kirk, "Review Marine Pharmacology in 2005-2006 Antitumour and Cytotoxic Compounds," European Journal of Cancer, vol. 44, no. 16, pp. 2357-2387, November 2008.

[50] G Barnathan, J Mirallès, E M Gaydou, N B Esnault, and J M Kornprobst, "New Phospholipid Fatty Acids from the Marine Sponge Cinachyrella Alloclada Uliczka," Lipids, vol. 27, no. 10 , pp. 779-784, October 1992.

[51] G Barnathan et al., "Phospholipid Fatty Acids and Sterols of two Cinachyrella Sponges from the Saudi Arabian Red Sea: Comparison with Cinachyrella Species from Other Origins," Comparative Biochemistry and Physiology Part B: Biochemistry and Molecular Biology, vol. 135, no. 2, pp. 297-308, June 2003.

[52] K Chairman and J A R Singh, "Cytotoxic Activity of Sponge Extract and Cancer Cell Lines from Selected Sponges," Biomaterial and Biomedicine, vol. 2, no. 1, pp. 1-5, February 2013.

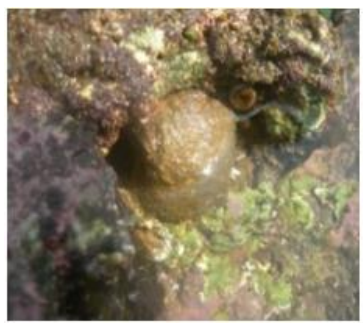

A

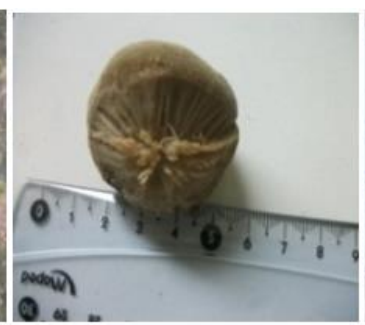

B

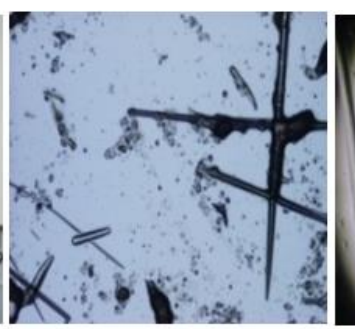

C

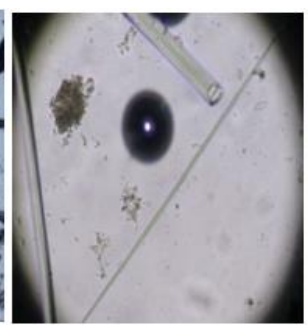

D

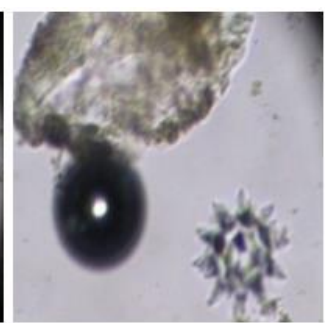

$\mathrm{E}$

Figure 1. Characteristics of marine sponges Cinachyrella sp. a. Morphology of Cinachyrella sp. attached under a rock, b. Cross sections of Cinachyrella sp. viewed from below, c. Preparations microscopic of Cinachyrella sp., Magnification 10x; d. Style of Cinachyrella sp., Magnification 10x e. Megasclera of Cinachyrella sp. 10x magnification.

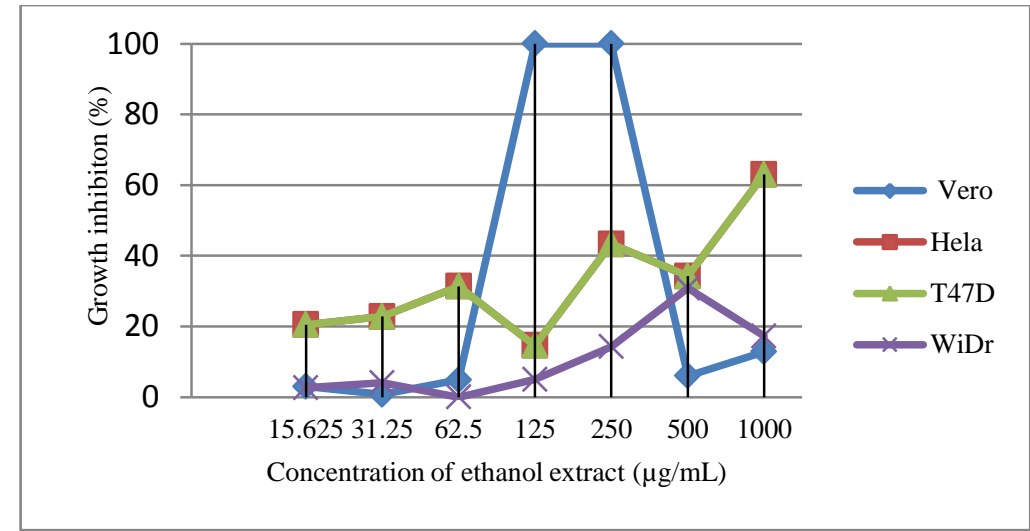

Figure 2. Cytotoxicity of ethanol extract Cinachyrella sp. on cell lines (Hela, T47D, WiDr and Vero) at a 24-h incubation time along with normal cell lines Vero. Cell viability was measured using the MTT assay and expressed as the percentage of treated samples to untreated control samples.

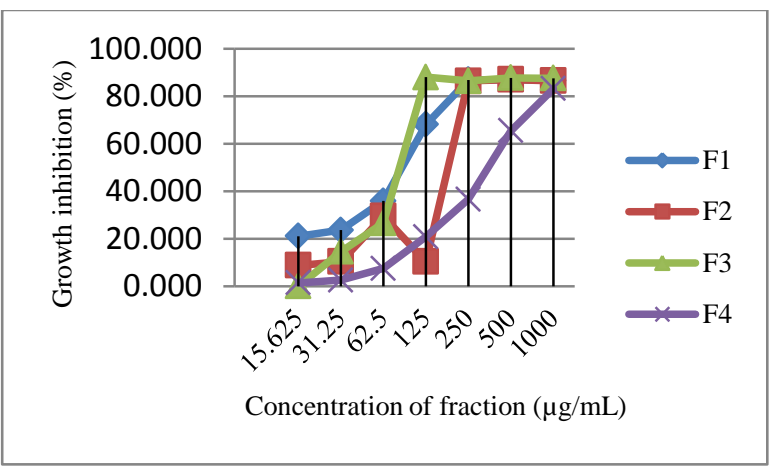

Figure 3. Cytotoxicity of the fraction (F1, F2, F3 and F4) Cinachyrella sp. on cell lines T47D at a $24-\mathrm{h}$ incubation time. Cell viability was measured using the MTT assay and expressed as the percentage of treated samples to untreated control samples.

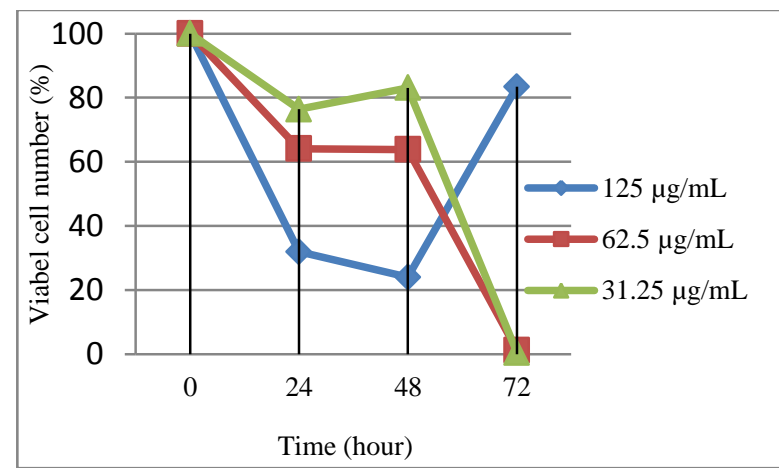

Figure 4. Antiproliferative effect of active isolate of the fraction F1 Cinachyrella sp. on cell lines T47D. 


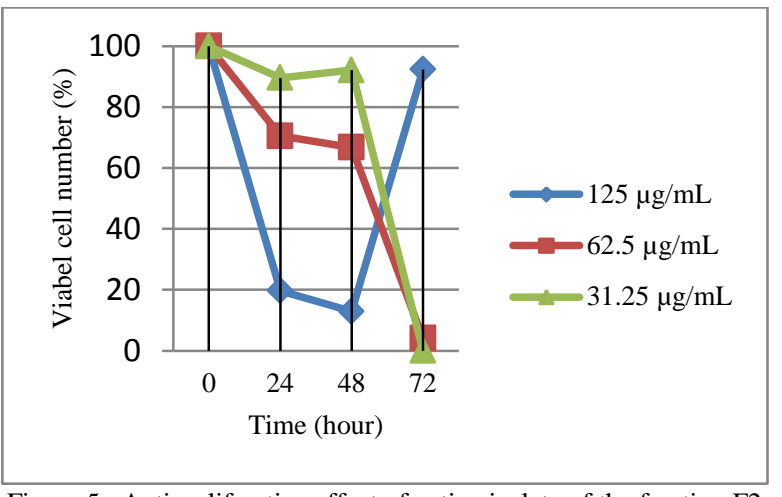

Figure 5. Antiproliferative effect of active isolate of the fraction F2 Cinachyrella sp. on cell lines T47D.

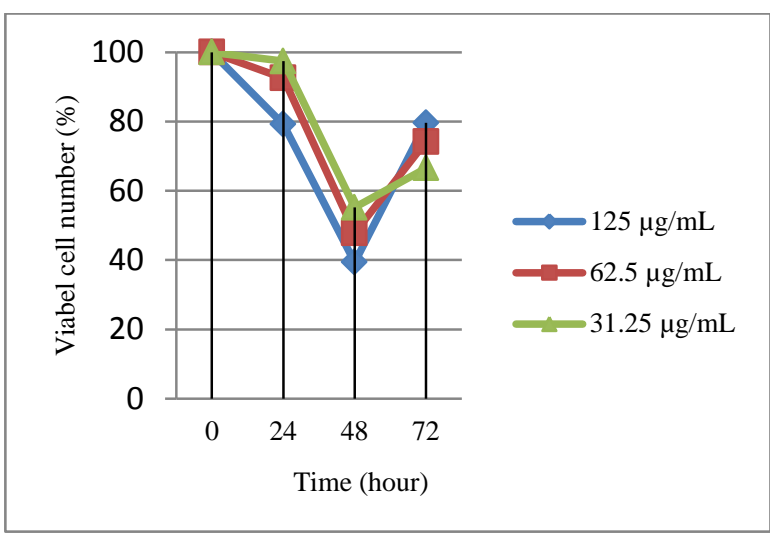

Figure 7. Antiproliferative effect of active isolate of the fraction F4 Cinachyrella sp. on cell lines T47D.

TABLE 1.

THE CYTOTOXICITY OF ETHANOL EXTRACT OF THE MARINE SPONGE CYNACHYRELLA SP. AGAINST CELL LINES HELA, T47D,

\begin{tabular}{|c|c|c|c|c|}
\hline No & $\begin{array}{l}\text { Cell } \\
\text { lines }\end{array}$ & Type of cell & $\begin{array}{c}\mathrm{IC}_{50} \text { Ethanol } \\
\text { extract } \\
(\mu \mathrm{g} / \mathrm{mL})\end{array}$ & $\begin{array}{c}\mathrm{IC}_{50} \\
\text { Doxorubicin } \\
(\mu \mathrm{g} / \mathrm{mL})\end{array}$ \\
\hline 1 & Vero & $\begin{array}{l}\text { Normal cell } \\
\text { line }\end{array}$ & $>1000$ & $>1000$ \\
\hline 2 & Hela & $\begin{array}{c}\text { Servix } \\
\text { cancer cell } \\
\text { line }\end{array}$ & 897.809 & 10.062 \\
\hline 3 & $\mathrm{~T} 47 \mathrm{D}$ & $\begin{array}{c}\text { Breast } \\
\text { cancer cell } \\
\text { line }\end{array}$ & $>1000$ & 32.974 \\
\hline 4 & WiDr & $\begin{array}{c}\text { Colon } \\
\text { cancer cell } \\
\text { line }\end{array}$ & $>1000$ & 14.93 \\
\hline
\end{tabular}

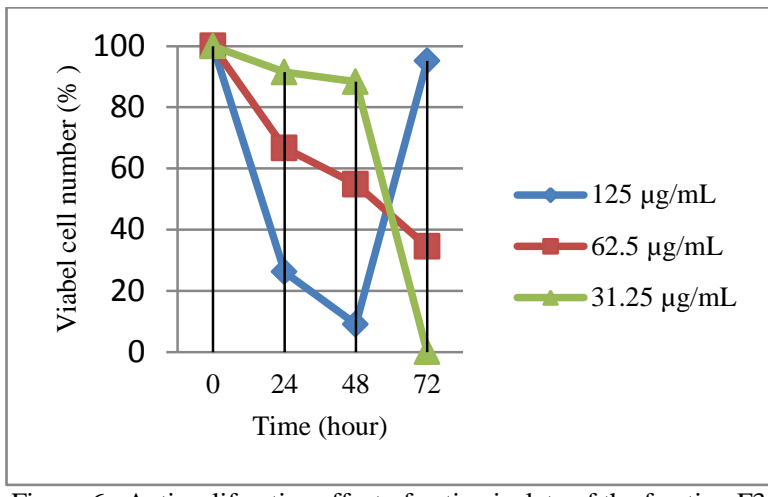

Figure 6. Antiproliferative effect of active isolate of the fraction F3 Cinachyrella sp. on cell lines T47D.

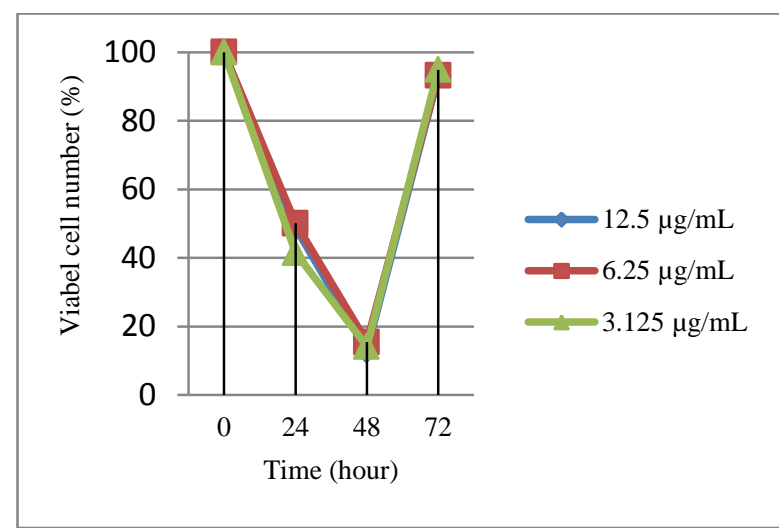

Figure 8. Antiproliferative effect of Doxorubicine on cell lines T47D.

TABLE 2.

The Cytotocity of Active Isolate of The Fraction (F1, F2, F3 AND F4) CINACHYRELLA SP. ON CELL LINES T47D AT A 24-H

\begin{tabular}{ccc}
\multicolumn{3}{c}{ INCUBATION TIME. } \\
\hline No & $\begin{array}{c}\text { Treatment } \\
\text { of fraction }\end{array}$ & $\begin{array}{c}\mathrm{IC}_{50} \\
\mu \mathrm{g} / \mathrm{mL}\end{array}$ \\
\hline 1 & $\mathrm{~F} 1$ & 82.44 \\
2 & $\mathrm{~F} 2$ & 163.679 \\
3 & $\mathrm{~F} 3$ & 66.522 \\
4 & $\mathrm{~F} 4$ & 333.026 \\
5 & Doxorubicin & 9.33 \\
\hline
\end{tabular}

TABLE 3.

REGRESSION EQUATION OF ANTIPROLIFERATIVE EFFECT OF ACTIVE ISOLATES (F1, F2, F3 AND F4) CINACHYRELLA SP. ON CELL LINE T47D.

\begin{tabular}{ccccc}
\hline \hline $\begin{array}{c}\text { Active isolate of } \\
\text { fractionation }\end{array}$ & $\begin{array}{c}\text { Concentration of the } \\
\text { fraction }(\mu \mathrm{g} / \mathrm{mL})\end{array}$ & Equation & Slope $(\alpha)$ & $\begin{array}{c}\mathrm{R}^{2} \\
\text { (The correlation of coefficient) }\end{array}$ \\
\hline F 1 & 125 & $0.594(\mathrm{x})+20.385$ & 0.594 & 0.637 \\
& 62.5 & $(-) 0.576(\mathrm{x})+72.805$ & -0.576 & 0.753 \\
& 31.5 & $(-) 0.433(\mathrm{x})+71.077$ & -0.433 & 0.684 \\
F 2 & 125 & $0.450(\mathrm{x})+29.266$ & 0.450 & 0.681 \\
& 62.5 & $(-) 0.573(\mathrm{x})+74.977$ & -0.573 & 0.792 \\
& 31.5 & $(-) 0.286(\mathrm{x})+62.066$ & -0.286 & 0.735 \\
F3 & 125 & $0.721(\mathrm{x})+3.748$ & 0.721 & 0.981 \\
& 62.5 & $0.601(\mathrm{x})+17.530$ & 0.601 & 0.992 \\
& 31.5 & $(-) 0.432(\mathrm{x})+64.366$ & -0.432 & 0.997 \\
F 4 & 125 & $0.009(\mathrm{x})+47.385$ & 0.009 & 0.000 \\
& 62.5 & $(-) 0.436(\mathrm{x})+79.200$ & -0.436 & 0.167
\end{tabular}


IPTEK, The Journal for Technology and Science, Vol. 25, No. 3, April 2014

\begin{tabular}{ccccc} 
& 31.5 & $\begin{array}{c}(-) 0.776(\mathrm{x})+ \\
104.657\end{array}$ & -0.776 & 0.498 \\
Doxorubicin & 12.5 & $0.332(\mathrm{x})+30.867$ & 0.332 & 0.306 \\
& 62.5 & $0.341(\mathrm{x})+29.968$ & 0.341 & 0.306 \\
& 3.125 & $0.380(\mathrm{x})+28.955$ & 0.380 & 0.423 \\
\hline \hline
\end{tabular}

